\title{
Classifying Latin American Economies: A Degree of Informalisation Approach
}

\author{
Colin C. Williams ${ }^{1} \&$ Youssef Youssef ${ }^{2}$ \\ ${ }^{1}$ Management School, University of Sheffield, Sheffield, UK \\ ${ }^{2}$ Business School, Humber Institute of technology and Applied Learning, Toronto, Canada \\ Correspondence: Colin C. Williams, Management School, University of Sheffield, Sheffield, S1 4DP, UK. Tel: \\ 44-114-222-3476. E-mail: C.C.Williams@sheffield.ac.uk
}

Received: March 19, 2014

Accepted: April 9, 2014

Online Published: May 5, 2014

doi:10.5430/ijba.v5n3p73

URL: http://dx.doi.org/10.5430/ijba.v5n3p73

\begin{abstract}
Given the commonality of employment in the informal economy, this paper moves beyond classifying economies by the composition of their formal economies and instead classifies economies by their degree of informalisation. Analysing International Labour Organisation data on the varying level of employment in the informal economy across 16 Latin American economies, the outcome is to reveal a significant correlation between cross-national variations in the degree of informalisation and cross-national variations in GNP per capita, poverty and social contribution levels. The paper concludes by discussing the implications for theory and policy.
\end{abstract}

Keywords: informal sector, shadow economy, underground sector, varieties of capitalism, economic development, Latin America

\section{Introduction}

Reviewing the dominant classificatory schemas for differentiating economies, it becomes quickly obvious that countries are distinguished by the nature of their formal economic systems, such as their level of Gross Domestic Product (GDP) per capita (World Bank, 2013), whether they are control, market or mixed economies (Arnold, 1996; Rohlf, 1998), or liberal or coordinated varieties of capitalism (Hall and Soskice, 2001). The problem, however, is that that the majority of the global labour force are working in jobs outside the formal economy (Jütting and Laiglesia, 2009; ILO, 2012, 2013; Williams and Lansky, 2013). Recognising this, the aim of this paper is to develop a classificatory schema for differentiating economies according to their degree of informalisation. The intention in doing so is to de-centre the formal economy in economic discourse and bring to the fore the prevalence of employment in the informal economy so that greater attention is paid to understanding this realm where the majority of global jobs are found and how it can be addressed in policy.

In the first section, therefore, a brief review will be undertaken of how to economies have been classified according to the character of their formal economic systems and an alternative typology will be provided that classifies economies according to their degrees of informalisation along with a review of the competing theories that have sought to explain the cross-national variations in the level of employment in the informal economy. In order to start to populate this classificatory schema and evaluate the competing explanations for the cross-national variations, the second section then introduces an ILO data set on the level of informal employment in 16 Latin American countries and the third section reports the descriptive findings on the cross-national variations in the degree of informalisation. The fourth section then conducts a preliminary evaluation of the competing explanations for these cross-national variations whilst the fifth and final section concludes by summarising the findings and discussing their theoretical and policy implications.

\section{Classifying Economic Systems: A Degrees of Informalisation Approach}

Reviewing the dominant classificatory schemas used to differentiate economies, it becomes quickly apparent that these classificatory schemas near enough entirely distinguish economies by the character of their formal economic systems. Such classificatory schemas range from simple schemas that compare countries according to their different levels of Gross Domestic Product (GDP) or Gross National Income (GNI) per capita (ILO, 2012; World Bank, 2013) through to analyses of different varieties of capitalism which distinguish whether countries have control, market or mixed 
economies (Arnold, 1996; Rohlf, 1998), or liberal or coordinated varieties of capitalism (Hall and Soskice, 2001).

The problem with classifying economies in this manner, however, is that they are what Gibson-Graham (2008) term 'capitalocentric', giving primacy to formal economic systems and ignoring how the vast majority of work across the world is undertaken beyond the formal economy. As Jütting and Laiglesia (2009) point out, some 60 percent of all jobs globally are in the informal economy, although the proportion which is in the informal economy is much lower in the countries of the minority world of the global North than in the majority world of the global South (ILO, 2012; Schneider and Williams, 2013). To classify economies by their formal economic systems, therefore, is not only to privilege the economic systems of global North but also to classify them using a segment of the economy that employs only a minority of the workforce. Here, therefore, the intention is to use a simple schema for classifying economies which recognises that the majority of work globally is in the informal economy and differentiates economies according to their degree of informalisation. This, moreover, is a classificatory scheme that is more appreciative of the extent to which the formal economy is relatively weak in the economies of the global South and employment concentrated in the informal economy.

Figure 1 provides a schema for classifying economies by their degree of informalization (i.e., the proportion of the non-agricultural workforce in employment in the informal economy). This differentiation of economies by their degree of informalisation, however, requires care. As Massey (2005) asserts, it has been sometimes assumed that there is a natural and inevitable trajectory towards the left of the continuum (i.e., formalization) and that countries can be placed in a hierarchical 'development queue' with the more formal economies of the global North on the left of the spectrum normatively positioned at the front and the more informal economies of the global South normatively placed at the back and also 'backwards' compared with more formalised economic systems (Geertz, 1963; Lewis, 1959).

\begin{tabular}{|c|c|c|c|c|c|c|c|c|c|}
\hline $\begin{array}{l}\text { Nearly } \\
\text { formal }\end{array}$ & $\begin{array}{l}\text { Dominantly } \\
\text { formal }\end{array}$ & $\begin{array}{l}\text { Largely } \\
\text { formal }\end{array}$ & $\begin{array}{l}\text { Mostly } \\
\text { formal }\end{array}$ & Semi-formal & Semi-informal & $\begin{array}{l}\text { Mostly } \\
\text { informal }\end{array}$ & $\begin{array}{l}\text { Largely } \\
\text { informal }\end{array}$ & $\begin{array}{l}\text { Dominantly } \\
\text { informal }\end{array}$ & $\begin{array}{l}\text { Nearly } \\
\text { informal }\end{array}$ \\
\hline 0 & 10 & 20 & 30 & 40 & 50 & 60 & 70 & 80 & 90 \\
\hline
\end{tabular}

Figure 1. Classification of economies: by degree of informalisation

However, the argument here is firstly, that the place occupied on this continuum does not signify normative superiority but rather, difference and secondly, that formalisation should not be privileged as a natural and inevitable universal trajectory. The lived practice is that economies are moving in different directions along this continuum (Schneider, 2013; Williams, 2007) and thus the future is not closed. How, therefore, can employment in the informal economy be defined? And how can the position an economy occupies on this spectrum be explained?

\subsection{Defining Employment in the Informal Economy}

To define employment in the informal economy, so as to determine the degree of informalization of economies, the widely accepted enterprise-based definition of the informal sector and jobs-based definition of informal employment developed by the 15th and 17th International Conference of Labour Statisticians (ICLS) respectively is here used (Hussmans, 2005; ILO, 2011, 2012). As Table 1 graphically portrays, when the enterprise is the unit of analysis the informal sector includes both formal and informal jobs in informal sector enterprises $(1+2)$, whilst when jobs are the unit of analysis informal employment includes informal jobs in both informal and formal enterprises $(1+3)$. Here, both units of analysis are used. 'Employment in the informal economy' $(1+2+3)$ includes all persons who in their main job are employed either in the informal sector $(1+2)$ or in informal employment $(1+3)$. If workers belong to both categories, they are counted only once.

Table 1. Defining the scope of informalisation

\begin{tabular}{lcc}
\hline Economic units & Informal employment & Formal employment \\
\hline Informal enterprises & 1 & 2 \\
\hline Formal enterprises & 3 & 4 \\
\hline
\end{tabular}

Source: derived from ILO (2012)

In order to define 'employment in the informal economy', therefore, firstly, informal sector enterprises must be defined and secondly, informal jobs must be defined. Here, the definition of the informal sector adopted by the 15th 
International Conference of Labour Statisticians in 1993 is used. This defines the 'informal sector' as composed of private unincorporated enterprises that are unregistered or small in terms of the number of employed persons. An unincorporated enterprise is a production unit not constituted as a legal entity independent of the individual (or group of individuals) who owns it, and for which no complete set of accounts is kept. An unregistered enterprise is one not registered under specific forms of national legislation (e.g., tax or social security laws, factories' or commercial acts, professional groups' regulatory acts). Possessing a trade license or business permit under local regulations does not qualify as registration. An enterprise is defined as small, meanwhile, when the number of employees is below a specific threshold (e.g., five employees) determined nationally (Hussmans, 2005; ILO, 2011, 2012).

The informal sector, however, fails to include those in informal employment in formal enterprises. Here, therefore, the definition of 'informal employment' adopted by the 17th ICLS in 2003 is used. This defines a job as being informal employment when it lacks basic social or legal protections or employment benefits and this job may be found in the formal sector, informal sector or households. Persons in informal employment, therefore, include not only employees holding jobs in formal or informal enterprises or households as paid domestic workers, but also a range of own-account workers including employers, sole traders, members of informal producers' cooperatives not established as legal entities and contributing family workers in formal or informal enterprises. Employees are deemed to be in informal employment if their employment relationship is, in law or in practice not subject to national labour legislation, income taxation, social protection or certain employment benefits are absent, such as paid annual or sick leave, advance notice of dismissal or severance pay (ILO, 2011: 12).

In this paper, therefore, employment in the informal economy $(1+2+3)$ includes all workers employed in informal sector enterprises $(1+2)$ and those in informal employment working in formal enterprises (3). Given this definition which allows the degree of informalisation of economies to be determined, attention now turns towards how can the position an economy occupies on this spectrum can be variously explained.

\subsection{Explaining Variations in the Degree of Informalisation}

Until now, three competing theoretical perspectives have variously sought to explain the differences in the degree of informalization between countries. These are modernization theory which associates higher levels of informalization with economic under-development, neo-liberal theory which associates it with high taxes, corruption and state interference and political economy theory which associates informalization with inadequate state intervention to protect workers from poverty. Each is here briefly reviewed in turn.

Modernisation theory, which dominated thought for much of the twentieth century, is based on the assumption that employment in the informal economy is a remnant from a pre-modern mode of production and is fading as the modern formal economy becomes ever more dominant (Geertz, 1963; Gilbert, 1998; Lewis, 1959; Packard, 2007). From this perspective, therefore, the continuing prevalence of employment in the informal economy is a product of economic under-development and will disappear with economic advancement and modernisation. Cross-national variations in the degree of informalisation, in consequence, are conceptualised in a temporally and normatively hierarchical manner. It represents the relative level of economic advancement and progress countries have made along the natural and inevitable linear trajectory towards formalisation. As such, countries are placed in a hierarchical development queue with nations at the front being 'advanced', 'modern' and 'progressive' and nations at the back of the queue wit high levels of informalisation deemed 'backward', 'traditional' and 'under-developed' (Geertz, 1963; Gilbert, 1998; Lewis, 1959; Packard, 2007).

In recent decades, however, modernisation theory has been subject to heavy criticism. This is because it has been recognised that in many countries and global regions, the majority of jobs are in the informal economy (ILO, 2011, 2012, 2013; Jütting and Laiglesia, 2009; Rodgers and Williams, 2009; Schneider, 2013; Schneider and Williams, 2013) and that not all economies are on a trajectory towards formalisation (Buehn and Schneider, 2012; Feld and Schneider, 2010; Rani et al., 2013; Renooy et al., 2004; Schneider, 2011). The result is that alternative theorisations have emerged to explain the differences in the degree of informalization between countries. Each is here reviewed in turn (see Williams and Lansky, 2013 for a fuller discussion).

On the one hand, a neo-liberal theory has emerged which deems the persistence and even expansion of employment in the informal economy to be a populist reaction to high taxes, a corrupt state system and too much interference in the free market. This results in workers making a rational economic decision to voluntarily exit the formal economy in order to avoid the costs, time and effort involved in formal registration (e.g., Becker 2004; De Soto 1989 2001; London and Hart 2004; Nwabuzor 2005; Perry and Maloney 2007; Sauvy 1984; Small Business Council 2004). As Nwabuzor (2005, p. 126) asserts, 'Informality is a response to burdensome controls, and an attempt to circumvent them'. The consequent solution is to pursue tax reductions, reduce corruption, deregulation and minimal state 
intervention. For adherents to this neo-liberal approach, therefore, the degree of informalisation will be greater in countries with higher tax levels and public sector corruption and greater state interference.

On the other hand, and in stark contrast, a political economy theory has asserted that the persistence and growth of employment in the informal economy is a direct result of the emergence of a de-regulated open world economy (Castells and Portes 1989; Gallin 2001; Hudson 2005; Portes 1994; Sassen 1996; Slavnic 2010; Taiwo, 2013). From this perspective, the increasing functional integration of a single global economic system is resulting in outsourcing and subcontracting becoming a primary vehicle for integrating employment in the informal economy into formal market production systems, causing a downward spiral of wages along with the erosion of incomes and social protection, and the consequent growth of further employment in the informal economy. Employment in the informal economy thus represents a largely unregulated, low paid and insecure form of work undertaken out of necessity and as a last resort by marginalised populations excluded from formal work and welfare arrangements (Castells and Portes 1989; Davis 2006; Gallin 2001; Hudson 2005; ILO 2002; Sassen 1996). The degree of informalisation from this theoretical standpoint, therefore, will be greater in economies characterised by inadequate state intervention to protect workers from poverty.

Until now, most commentators explaining variations in the degree of informalisation of economies have done so by supporting just one of these perspectives (e.g., Schneider, 2008; Yamada, 1996). Recently, nevertheless, a more nuanced perspective has started to emerge that views each perspective as more relevant in some contexts rather than others, and seeks to combine them so that a richer finer-grained understanding be achieved. For example, it has been argued that the political economy explanation is more relevant to relatively deprived populations and the neo-liberal explanation to relatively affluent populations within countries (Evans et al., 2006; Gurtoo and Williams, 2009; Pfau-Effinger, 2009; Williams et al., 2012) and that neo-liberal exit rationales are more common in developed economies and political economy exclusion rationales in developing economies (Oviedo et al., 2009).

So far, the only studies evaluating critically the validity of these competing explanations in relation to the variations in the degree of informalisation across countries focus upon the member states of the European Union and find evidence to support both the modernisation and political economy explanations but no support for the neo-liberal explanation (Eurofound, 2013; Vanderseypen et al., 2013; Williams, 2013). No studies have yet evaluated the validity of these competing explanations for the cross-national variations in the degree of informalisation in relation to the developing world. This paper therefore seeks to fill that gap. Is the conventional 'modernisation' thesis valid that wealthier developing economies have lower degrees of informalisation than poorer developing economies? Is the neo-liberal approach valid that the degree of informalisation is higher in developing economies with greater public sector corruption, higher taxes and more state interference in work and welfare? Or is the political economy approach valid that the degree of informalisation is higher in developing countries with greater poverty and less protection of workers forcing marginalised populations into such endeavour in the absence of alternatives? To answer these questions, the variations in the degree of informalisation across 16 Latin American will be here analysed.

\section{Methodology: Examining the Degree of Informalisation of Latin American Economies}

To classify economies according to the degree of informalisation of their economic systems and evaluate the contrasting explanations for the cross-national variations in the degrees of informalisation, the International Labour Organisation (ILO) surveys on the extent of the informal sector and informal employment in 16 Latin American countries are here analysed. Indeed, this is the only cross-nationally comparable data currently available on the variations in the degree of informalisation of economies that employs a common definition and methodology across countries to collect data. Using an ILO Department of Statistics questionnaire sent to countries (for further details, see ILO, 2012), this survey excludes employment in agriculture, hunting, forestry and fishing. When analysing the share of the non-agricultural workforce involved in employment in the informal economy, moreover, it is the self-reported main job of people having more than one job that is counted, not least so as to avoid any small-scale odd-jobs in the informal economy being counted.

Meanwhile, and to select the indicators against which the competing explanations can be evaluated, the approach adopted is that proxy indicators for the various tenets of each theorisation are taken from the World Bank development indicators database for the year in which the survey was conducted in each country (World Bank, 2013). The only indicator taken from a non-official source is on perceptions of public sector corruption, extracted from Transparency International's corruption perceptions index for the relevant year in each country (Transparency International, 2013).

To evaluate the modernisation thesis, the indicator employed is that used in previous studies (ILO, 2012; Yamada, 1996), namely GNP per capita (ILO, 2012). To evaluate the neo-liberal thesis that the degree of informalisation is associated with high taxes, corruption and state interference in the free market, meanwhile, indicators previously used 
when evaluating the taxation assumption of neo-liberal thought are employed (Eurofound, 2013; Vanderseypen et al., 2013; Williams, 2013), namely the World Bank (2013) country-level data on:

Taxes on goods and services as a percentage of revenue. This includes general sales and turnover as well as value added taxes, excise duties on goods, taxes on services, taxes on the use of goods or property, taxes on extraction and the production of minerals and the profits of fiscal monopolies;

Taxes on income, profits and capital gains as a percentage of revenue. This covers taxes on the actual or presumptive net income of individuals, the profits of businesses and capital gains on land, securities and other assets.

Taxes on revenue (excluding grants) as a percentage of GDP. Revenue covers cash receipts from taxes, social contributions and other revenues (e.g., fines, fees, rent and income from property or sales).

Tax revenue as a percentage of GDP. Tax revenue includes compulsory transfers to central government for public purposes including fines and penalties. Most social security contributions are excluded. Refunds of wrongly collected tax revenue are treated as negative revenue.

Total tax rate as percentage of commercial profits. This includes all taxes and mandatory contributions payable by organizations after allowable deductions and exemptions, as a share of commercial profits. Taxes withheld (e.g., personal income tax) or paid to tax authorities (e.g., value added taxes, sales taxes or goods and service taxes) are not included.

Meanwhile, the neo-liberal public sector corruption tenet is evaluated using three indicators:

Transparency International's Corruption Perceptions Index (CPI), which is a composite index of perceptions of public sector corruption from 14 expert opinion surveys. It scores nations on a 0-10 scale, with zero indicating high levels and 10 low levels of perceived public sector corruption (Transparency International, 2013).

The percentage of firms making informal payments to public officials, and

The percentage of firms expected to give gifts in meetings with tax officials.

To analyse both the neo-liberal notion that state interference leads to greater degrees of informalisation and the contrary political economy theory that it is a result of inadequate levels of state intervention to protect workers from poverty, the World Bank indicators used are:

Time required to obtain an operating license;

The time required (in days) to start a business;

The time spent dealing with tax officials as a share of total management time;

The 'ease of doing business' ranking for each country from the World Bank Doing Business Surveys, which is a relative proxy indicator of the regulatory burden in each country;

The share of the population living below the national poverty line;

The generosity of social protection in each country, namely the percentage of the population receiving social protection which is adequate to have progressive effects on the distribution of well-being and help reduce poverty by providing adequate support to beneficiaries, and

The expense of government as a share of GDP, which covers cash payments for the operating activities of the government in terms of providing goods and services. It covers compensation of employees (e.g., salaries), interest and subsidies, grants, social benefits and expenses such as rent and dividends.

To analyse the relationship between cross-national variations in the degree of informalisation and these economic and social conditions that each theory suggests are associated, and given the small sample size of just 16 countries and lack of necessary controls to include in a multivariate regression analysis, it is only possible here to conduct bivariate regression analyses. To do this, Spearman's rank correlation coefficient (rs) is employed due to the non-parametric nature of the data. Nevertheless, and as will be seen below, despite this limitation, some meaningful findings are still produced regarding the validity of these theories.

Firstly, therefore, the variable degree of informalisation in these 16 Latin American countries will be reported and secondly, a preliminary analysis will be conducted of the validity of the wider economic and social conditions that each theorisation deem to be associated with higher degrees of informalisation in order to evaluate the competing theories. 


\section{Findings: Classifying Latin American Economies by Their Degrees of Informalisation}

Examining the 16 Latin American economies covered by the ILO data, 58.2 percent of the non-agricultural workforce is employed in their main job in the informal economy. This, however, is an unweighted average. Taking into account the variable size of the workforce across these economies, the weighted average is 51.1 percent. Employment in the informal economy, therefore, is not some minor residue existing in a few marginal enclaves. The majority of the non-agricultural workforce across these 16 Latin American economies is engaged in employment in the informal economy.

However, there are some marked differences across countries. As Table 2 reports, the proportion of the non-agricultural workforce employed in the informal economy ranges from 75.6 percent in Bolivia to 42.3 percent in Uruguay. Nevertheless, in ten of the sixteen (62 percent) of the Latin American countries surveyed, the majority of the non-agricultural workforce is employed in the informal economy. Much of this work, as can be seen in Table 2, is conducted on an own-account basis, ranging from 82 percent of all employment in the informal economy in Colombia to 53.6 percent in Paraguay. However, there is no significant correlation between the proportion of the non-agricultural workforce employed in the informal economy and the proportion of the informal workforce that is self-employed.

Table 2. Employment in the informal economy as \% of non-agricultural workforce in 16 Latin American countries

\begin{tabular}{|c|c|c|c|c|}
\hline Country & Year & $\begin{array}{l}\text { Employment in the } \\
\text { informal economy } \\
\text { as } \% \text { of } \\
\text { non-agricultural } \\
\text { employment }\end{array}$ & $\begin{array}{ll}\% & \text { of } \\
\text { employment in } \\
\text { informal } \\
\text { economy that is } \\
\text { own-account } \\
\text { work }\end{array}$ & Type of economy \\
\hline Bolivia & 2006 & 75.6 & 68.3 & Largely informal \\
\hline Honduras & 2009 & 75.3 & 75.6 & Largely informal \\
\hline Paraguay & 2009 & 70.7 & 53.6 & Largely informal \\
\hline Peru & 2009 & 70.7 & 68.2 & Largely informal \\
\hline Nicaragua & 2009 & 69.4 & 73.1 & Mostly informal \\
\hline El Salvador & 2009 & 68.2 & 75.7 & Mostly informal \\
\hline Colombia & 2010 & 61.5 & 82.0 & Mostly informal \\
\hline Ecuador & 2009 & 61.3 & 60.2 & Mostly informal \\
\hline Mexico & 2009 & 54.3 & 61.7 & Semi informal \\
\hline Argentina & 2009 & 50.0 & 63.6 & Semi informal \\
\hline Dominican rep & 2009 & 48.8 & 59.6 & Semi formal \\
\hline Venezuela & 2009 & 48.2 & 74.1 & Semi formal \\
\hline Costa Rica & 2009 & 48.2 & 67.6 & Semi formal \\
\hline Panama & 2009 & 44.0 & 62.5 & Semi formal \\
\hline Uruguay & 2009 & 43.7 & 68.6 & Semi formal \\
\hline Brazil & 2009 & 42.3 & 57.2 & Semi formal \\
\hline
\end{tabular}

Source: derived from ILO (2012)

Positioning these Latin American countries on the continuum of Figure 1, therefore, and as the final column of Table 1 reveals, none of these Latin American countries have all non-agricultural workers employed in either the formal or informal economy, and there are no 'nearly', 'dominantly' or even 'largely' formal economies, nor 'dominantly informal' economies. Instead, these Latin American countries are clustered towards the centre of the spectrum, although slightly skewed towards the informalised side of the continuum; 37 percent are 'semi-formal' economies, 13 percent are 'semi-informal' economies, 25 percent 'mostly formal' economies and 25 percent are 'largely informal' economies.

Given these variations in the degree of informalisation of Latin American economies, attention now turns towards evaluating the different theoretical explanations for these cross-national variations.

\section{Analysis: Explaining the Variations in the Degree of Informalisation of Latin American Economies}

To evaluate critically the validity of the three theoretical explanations for the variations in the degree of informalisation of Latin American economies, the association between the cross-national variations in the degree of informalisation and the cross-national variations in the various characteristics that each perspective deems to be important determinants are here evaluated. 
Starting with modernisation theory which asserts that the degree of informalisation is greater in less developed economies, the correlation between cross-national variations in the degree of informalisation and cross-national variations in GNP per capita is analysed across these 16 Latin American economies. Using Spearman's rank correlation coefficient, and as Figure 2 graphically displays, there is a strong statistically significant relationship within a 99 percent confidence interval between the degree of informalisation and GNP per capita $\left(\mathrm{r}_{\mathrm{s}}=-.866^{* *}\right)$. The direction of this relationship is that the degree of informalisation is higher in economies with lower levels of GNP per capita. However, and akin to earlier studies reaching the same conclusion (ILO, 2012; Yamada, 1996), the direction of the correlation in terms of any cause-effect relationship cannot be established. This, in consequence, is a limitation of both this and previous studies.

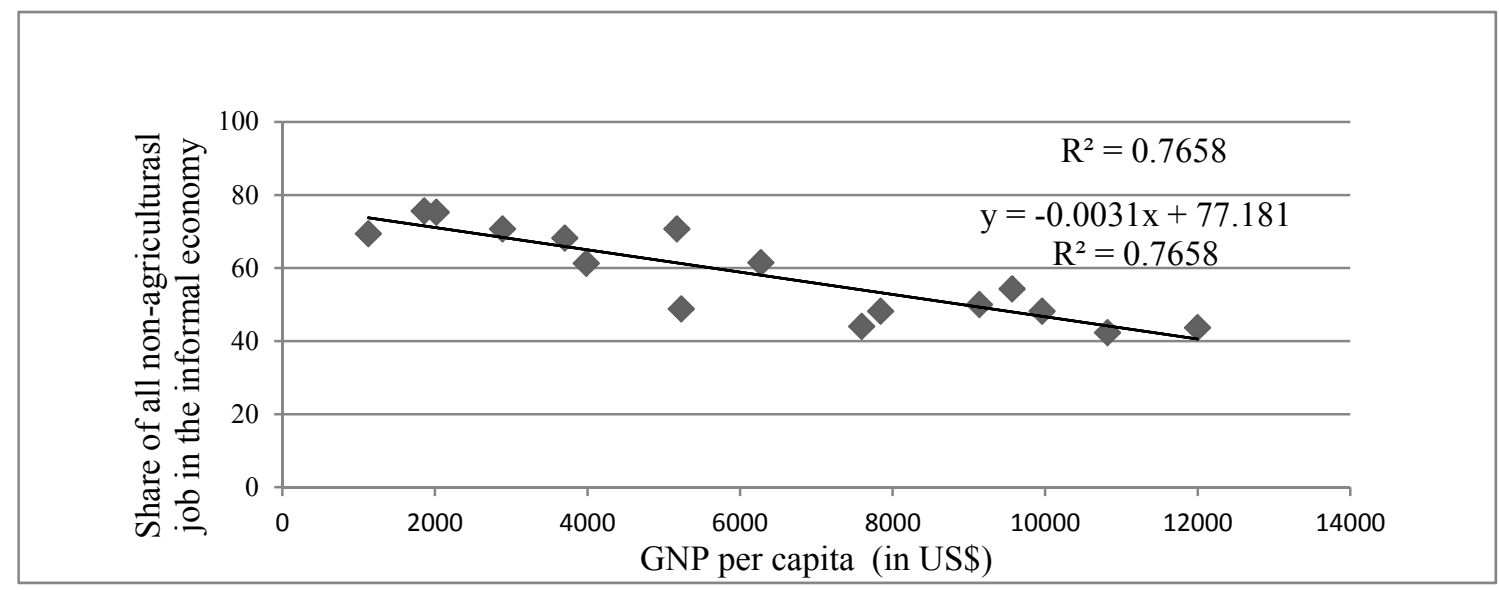

Figure 2. Relationship between degree of informalisation and GNP per capita

Turning to the neo-liberal theory which explains informalisation to be a result of higher taxation levels, public sector corruption and state interference in the operation of the free market, the first step is to analyse the neo-liberal tenet that informalisation is greater when tax rates are higher.

Beginning with the association between cross-national variations in the degree of informalisation and the level of taxes on goods and services as a share of revenue, the finding using Spearman's rank correlation coefficient due to the nonparametric nature of the data, is that there is no statistically significant relationship $\left(r_{s}=.347\right)$. Examining the relationship between the degree of informalisation and the level of taxes on income, profits and capital gains as a share of revenue, it is similarly the case that there is no significant relationship $\left(\mathrm{r}_{\mathrm{s}}=.073\right)$ and this is again the case when the cross-national variations in the level of taxes on revenue (excluding grants) as a share of GDP $\left(\mathrm{r}_{\mathrm{s}}=-.426\right)$, tax revenue as a percentage of GDP $\left(\mathrm{r}_{\mathrm{s}}=-.371\right)$ and the total tax rate $\left(\mathrm{r}_{\mathrm{s}}=-.111\right)$ are analysed. Cross-national variations in the degree of informalisation, in consequence, are not associated with taxation levels whichever tax indicator is analysed. There is thus no evidence to support the neo-liberal notion that the degree of informalisation is greater in countries with higher tax rates and that the remedy is to thus reduce tax rates. Indeed, these results in Latin America reinforce findings in Europe which similarly find no association between cross-national variations in tax rates and the degree of informalisation (Vanderseypen et al., 2013; Williams, 2013).

Turning to the neo-liberal assertion that the degree of informalisation is greater in countries with higher levels of public sector corruption, the finding using Transparency International's perceptions of public sector corruption index is that there is a significant association at the 0.05 level is identified between cross-national variations in the degree of informalisation and levels of perceived public sector corruption $\left(\mathrm{r}_{\mathrm{s}}=-.545^{*}\right)$. As Figure 3 reveals, the greater is the perceived level of public sector corruption in a country, the greater is the level of informalisation. This validates the public sector corruption tenet of the neo-liberal approach. However, when two further measures of actual rather than perceived public sector corruption are analysed, this is not the case. When the cross-national variations in the percentage of firms who make informal payments to public officials is compared with the cross-national variations in the degree of informalisation is analysed, no significant correlation is identified $\left(r_{s}=-.015\right)$. Neither is any statistically significant association identified between cross-national variations in the share of businesses who state that they are expected to give gifts in meetings with tax officials and cross-national variations in the level of informalisation $\left(\mathrm{r}_{\mathrm{s}}=-.276\right)$. Although one composite indicator of perceptions of public sector corruption thus provides some evidence to support the neo-liberal thesis regarding the association between public sector corruption and 
informalisation, more direct indicators investigating whether organisations are subject to corruption in practice do not find any significant correlation.

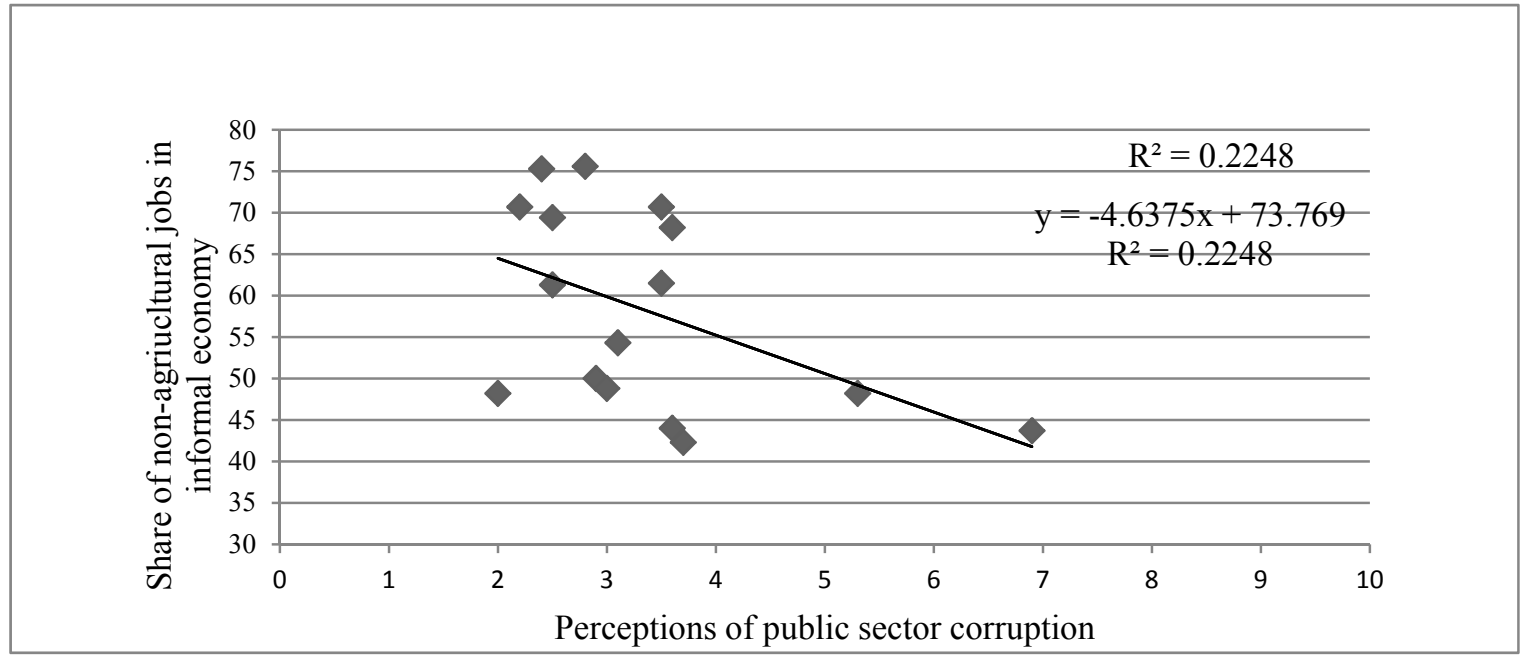

Figure 3. Relationship between degree of informalization and corruption

To evaluate the neo-liberal argument that state interference in the operation of the market leads to higher levels of informalisation, as well as the contrary political economy view that the degree of informalisation reduces with greater state intervention, a range of indicators can be analysed.

Comparing the cross-national variations in the degree of informalisation and cross-national variations in the time required in days to start a business, which is a surrogate indicator of whether there is a burdensome regulatory environment for start-ups, no significant association is identified $\left(\mathrm{r}_{\mathrm{s}}=-.256\right)$. Neither is a significant association found between cross-national variations in the degree of informalisation and either cross-national variations in the time spent dealing with officials as a percentage of management time by enterprise owners $\left(\mathrm{r}_{\mathrm{s}}=.189\right)$ or the World Bank's 'ease of doing business' ranking of countries, which is a relative proxy of the regulatory burden in countries $\left(\mathrm{r}_{\mathrm{s}}=.138\right)$. However, and as Figure 4 reveals, a statistically significant correlation at the 0.05 level is identified between cross-national variations in the degree of informalisation and cross-national variations in the time required in days to obtain an operating license $\left(\mathrm{r}_{\mathrm{s}}=.-548^{*}\right)$. The greater the number of days required to obtain an operating license, the lower is the level of informalisation, thus refuting the neo-liberal perspective and supporting the political economy perspective that the greater is the level of state intervention, in this case to protect working conditions, the lower is the level of informalisation.

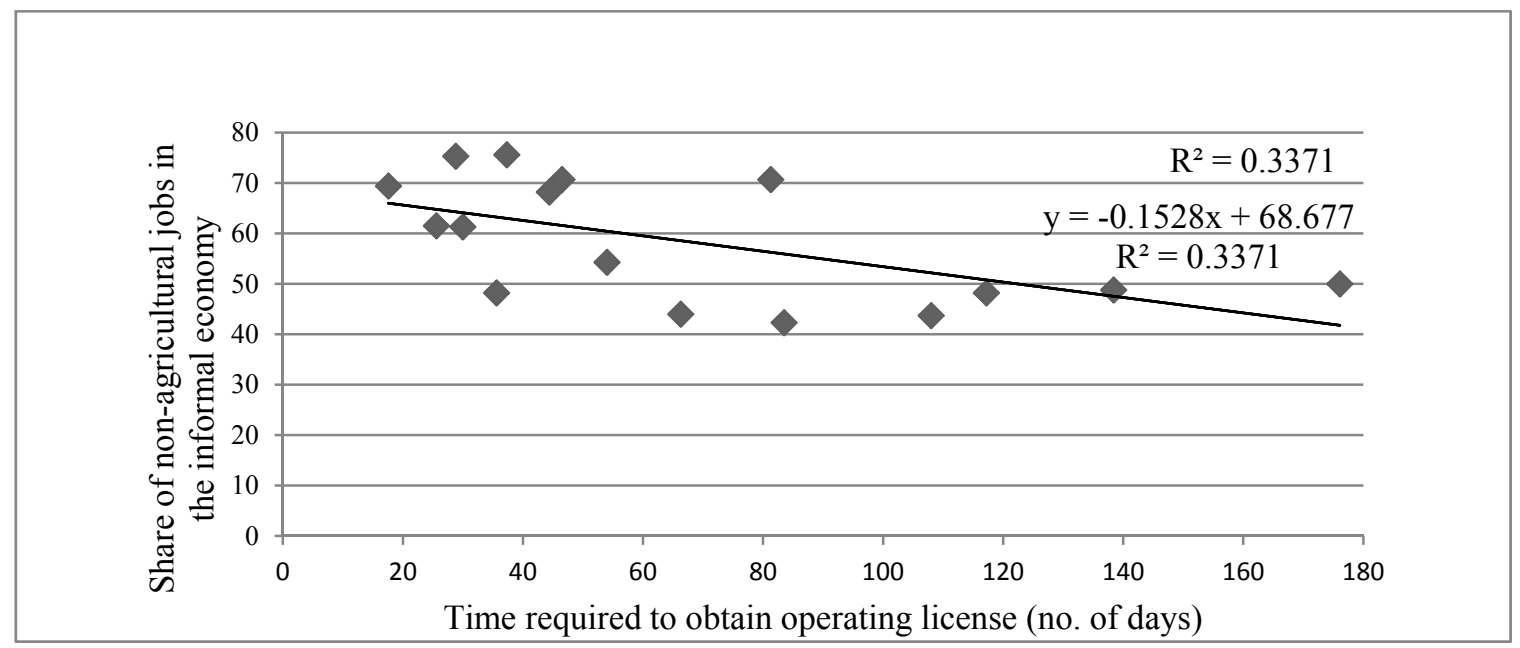

Figure 4. Relationship between degree of informalization and regulatory burden

Investigating whether state intervention in welfare arrangements increases the level of informalisation as neo-liberals assert, or decreases the degree of informalisation as political economists assert, the relationship between the expense of 
government as a share of GDP, which is a proxy of the degree to which governments intervene in work and welfare arrangements, and the degree of informalisation can be analysed. The finding is that there is a significant association at the 0.05 level $\left(\mathrm{r}_{\mathrm{s}}=-.562 *\right)$. The direction of the relationship is that bigger government reduces the level of informalisation. This thus refutes the neo-liberal thesis and supports the political economy standpoint that greater state intervention in work and welfare to protect workers from poverty reduces the level of informalisation.

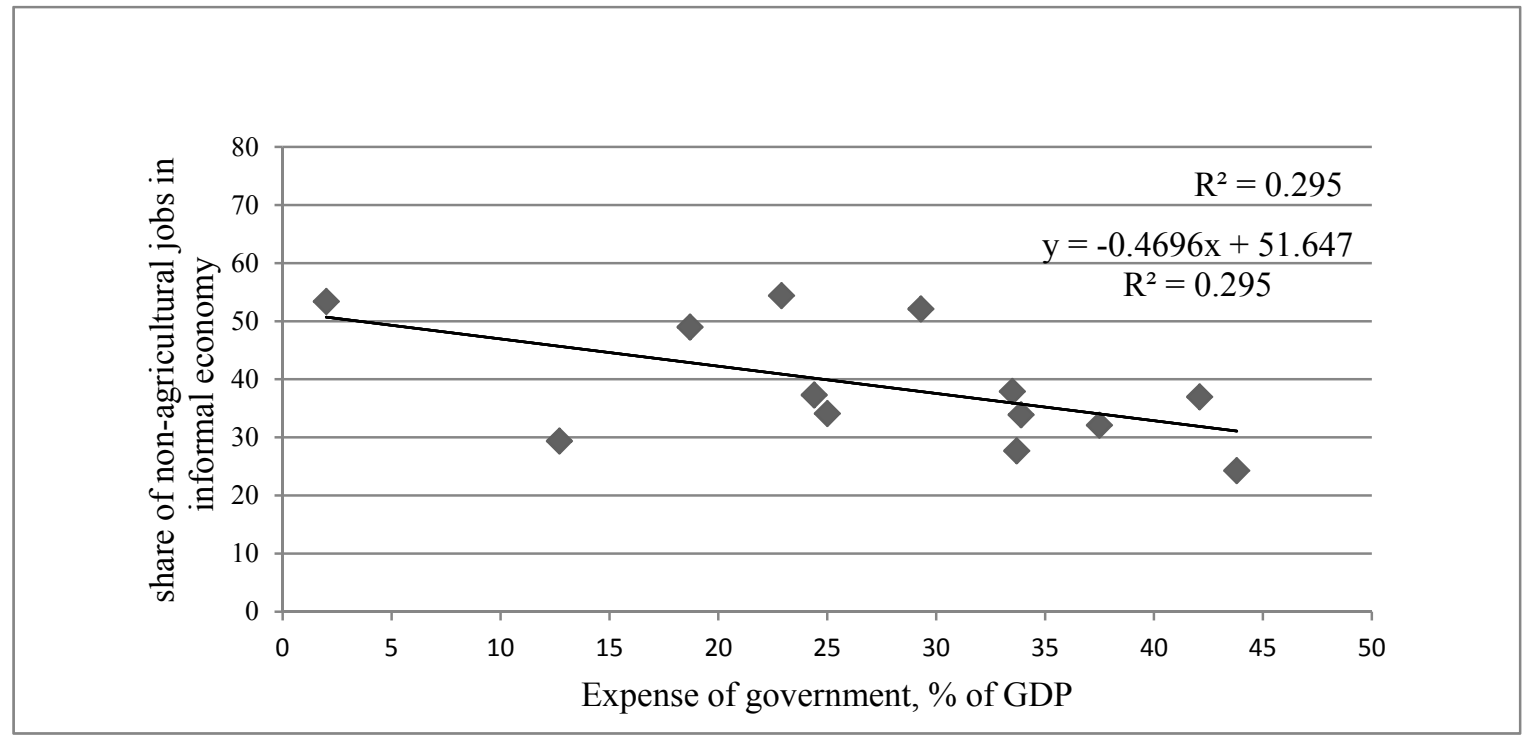

Figure 5. Relationship between degree of informalization and size of government

Indeed, to evaluate further this political economy theorisation that the degree of informalisation will be greater in economies characterised by inadequate state intervention to protect workers from poverty, the relationship between cross-national variations in the level of informalisation and cross-national variations in the proportion of the population living below the national poverty line can be analysed. As Figure 6 reveals, there is a strong statistically significant relationship at the 0.01 level $\left(\mathrm{r}_{\mathrm{s}}=.728^{* *}\right)$. The greater is the share of the population living below the national poverty line, the higher is the level of informalisation.

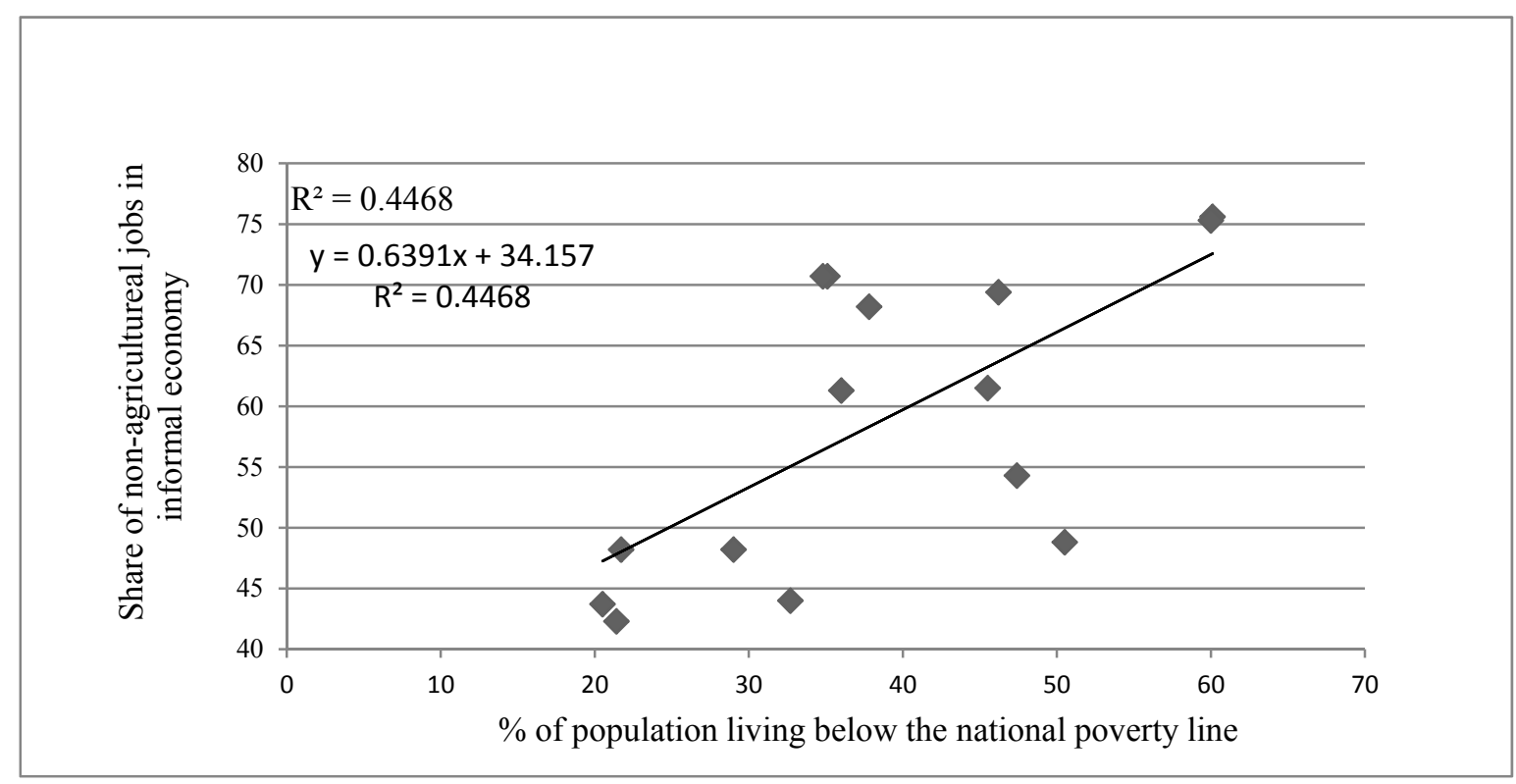

Figure 6. Relationship between degree of informalization and \% of population living below national poverty line

It is also the case that there is a significant association between cross-national variations in the level of informalisation and the level of state intervention in social protection. As Figure 7 reveals, a statistically significant relationship at the 
0.05 level is found between cross-national variations in the degree of informalisation and the generosity of all social protection as measured by the World Bank $\left(\mathrm{r}_{\mathrm{s}}=-.575^{*}\right)$. The higher is the coverage and generosity of social protection, the lower is the level of informalisation. This thus refutes the neo-liberal perspective and instead supports the political economy explanation that greater state intervention to protect workers from poverty reduces the level of informalisation since it provides an alternative means of support and prevents marginalised populations turning to informal employment as a last resort.

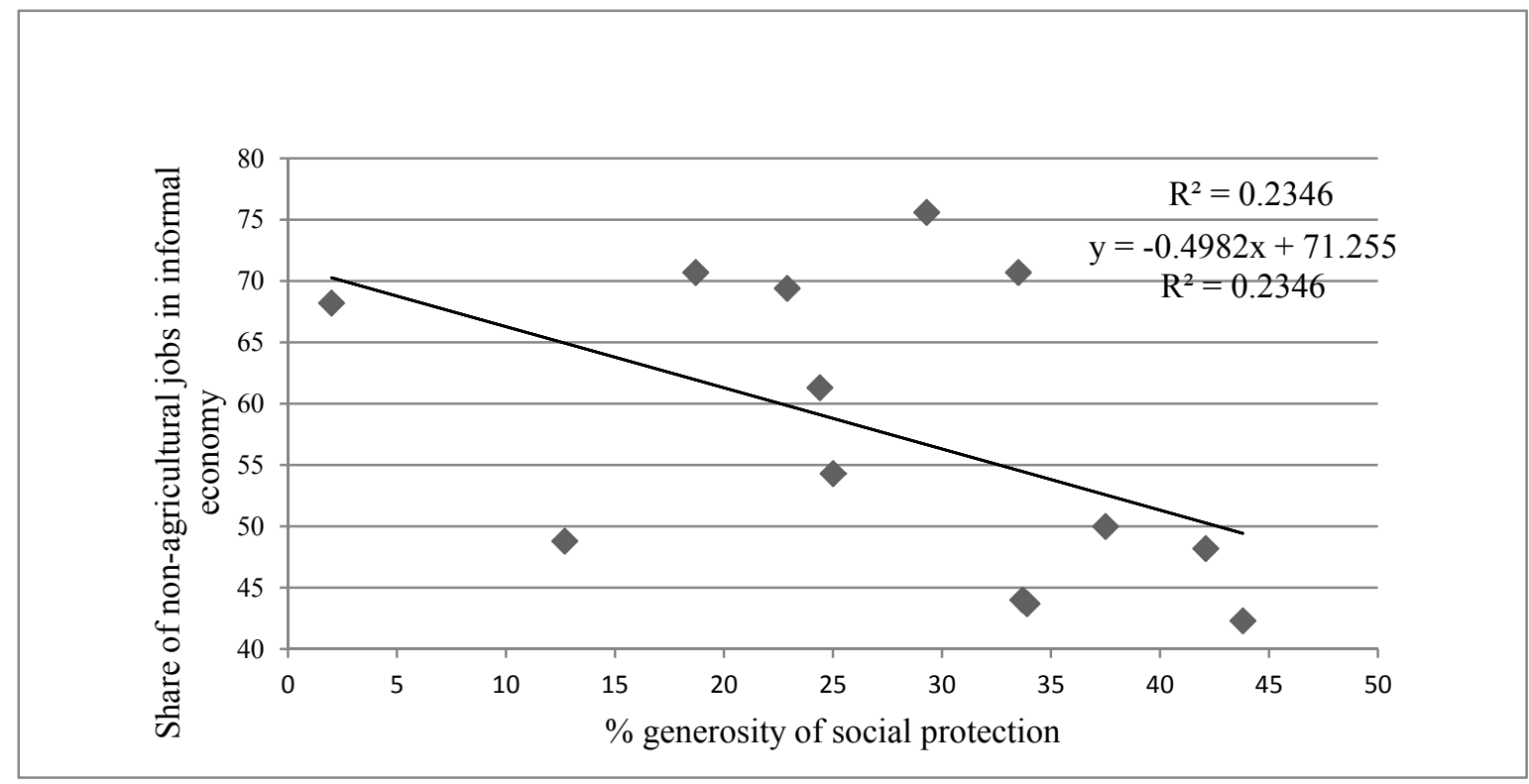

Figure 7. Relationship between degree of informalization and generosity of social protection

\section{Conclusions}

This paper has provided a typology of economies that places countries on a continuum in terms of their degree of informalisation. Analysing the results of ILO surveys conducted in 16 Latin American countries, the finding is that the majority (51.1 percent) of the non-agricultural workforce have their main employment in the informal economy. Employment in the informal economy, in consequence, is not some small segment of the labour market in these countries of marginal importance. Indeed, in ten of the sixteen countries, it is the informal economy that employs the majority of workers and the formal economy which employs the minority of the workforce and is marginal in terms of employment. Nevertheless, marked cross-national variations exist in terms of the proportion of the workforce employed in the informal economy, ranging from 75.6 percent of the non-agricultural workforce in Bolivia to 42.3 percent in Uruguay.

Analysing the reasons for these cross-national variations in the degree of informalisation, three competing explanations have been critically evaluated which argue that the degree of informalisation is associated with economic under-development (modernisation thesis), higher taxes, corruption and state interference (neo-liberal thesis) and/or inadequate state intervention to protect workers from poverty (political economy thesis). The evidence supports the modernisation and political economy explanations that associate greater informalisation with under-development and inadequate state protection of workers from poverty respectively. However, no evidence has been found to support the neo-liberal theory that greater informalisation is associated with higher taxes, corruption and more state interference, with the one exception that perceptions (although not the activities) of public sector corruption are found to be associated with informality. Indeed, on the whole, the findings support the opposite to the neo-liberal approach. More state intervention reduces the degree of informalisation, not least because of the ability of governments to make social transfers and therefore decrease the need for the population to turn to employment in the informal economy as a survival practice.

The theoretical outcome of this study of cross-national variations of the degree of informalisation, in consequence, is that a synthesis of previous explanations is required. Akin to the previous finding when studying the degree of informalisation in the advanced economies of the European Union (Williams, 2013), albeit using a data set that is not comparable with this data, the finding in Latin America is that greater degrees of informalisation are associated with lower GNP per capita and lower levels of state intervention in the form of social transfers to protect workers from 
poverty. A very tentative conclusion, in consequence, is that a synthesis of both the modernisation and political economy perspectives is required in the form of a new 'neo-modernisation' thesis that explains the lower degree of informalisation as associated with development and state intervention in the form of social transfers to protect workers from poverty. This now requires further evaluation in relation to a wider range of developed and developing economies as well as using time-series data for individual countries and, if possible, multivariate regression analysis on a larger sample size to determine how important each characteristic is to the final outcome whilst controlling for the other characteristics.

These findings also have implications for policy. At present, the policy debate surrounding employment in the informal economy is over whether targeted repressive measures and/or targeted incentives are the most appropriate for facilitating formalisation (Dibben and Williams, 2012; Eurofound, 2013; Feld and Larsen, 2012; OECD, 2012; Williams and Lansky, 2013; Williams and Nadin, 2012; Williams et al., 2013). This paper, however, displays that wider economic and social policy measures are also important. The overarching modernisation of economies, social protection and poverty alleviation are all closely associated with employment in the informal economy. Tackling employment in the informal economy, therefore, requires not only the development of targeted policy measures but also appropriate wider economic and social policies. In other words, targeted policy measures tailored to facilitating formalisation might be necessary but appear insufficient for tackling informality.

In sum, grounded in the recognition that the majority of the non-agricultural workforce has their main employment in the informal economy, this paper has adopted an alternative analytical framework for classifying economies according to the degree of informalisation of economies, thus transcending the conventional approach of differentiating economies according to the nature of their formal economies. This approach to classifying economies, of course, does not have to be viewed as an alternative to the conventional approach. Indeed, future research might well seek to combine these two approaches to classifying economies. If this paper thus encourages further research on classifying economies by their degree of informalisation, it will have achieved its intention. If it also leads to scholars to synthesis the conventional approach examining the character of formal economies with this new approach, and encourages greater investigation of both the determinants of informalisation as well as the broader economic and social policy remedies, then it will have achieved its wider objectives.

\section{References}

Arnold, R.A. (1996). Economics. West Publishing: St Paul MN.

Becker, K.F. (2004). The Informal Economy: fact finding study. Swedish International Development Agency, Stockholm.

Boeke, J.H. (1942). Economics and Economic Policy of Dual Societies as exemplified by Indonesia. Tjeenk Willnik, Harlem.

Buehn, A., \& Schneider, F. (2012). Shadow economies around the world: novel insights, accepted knowledge and new estimates. International Tax and Public Finance, 19(1), 139-71. http://dx.doi.org/10.1007/s10797-011-9187-7

Castells, M., \& Portes, A. (1989). World underneath: the origins, dynamics and effects of the informal economy. In Portes, A., Castells, M. and Benton, L.A. (Eds.), The Informal Economy: studies in advanced and less developed countries (pp. 11-39). John Hopkins University Press: Baltimore.

Davis, M. (2006). Planet of slums. Verso, London.

De Soto, H. (1989). The Other Path: the economic answer to terrorism. Harper and Row, London.

De Soto, H. (2000). The Mystery of Capital: why capitalism triumphs in the West and fails everywhere else. Basic Books, New York.

Dibben, P., \& Williams, C.C. (2012). Varieties of capitalism and employment relations: informally dominated market economies. Industrial Relations: A Review of Economy and Society, 51(S1), 563-82.

Eurofound. (2013). Tackling Undeclared Work in 27 European Union Member States and Norway: approaches and measures since 2008. Eurofound, Dublin.

European Commission. (2013). Employment and Social Developments in Europe 2013. European Commission, Brussels.

Evans, M., Syrett, S., \& Williams, C.C. (2006). Informal Economic Activities and Deprived Neighbourhoods. Department for Communities and Local Government, London. 
Feld, L.P., \& Larsen, C. (2012). Undeclared Work, Deterrence and Social Norms: the case of Germany. Springer Verlag, Berlin. http://dx.doi.org/10.1007/978-3-540-87401-0

Feld, L.P., \& Schneider, F. (2010). Survey on the shadow economy and undeclared earnings in OECD Countries. German Economic Review, 11(5), 109-49. http://dx.doi.org/10.1111/j.1468-0475.2010.00509.x

Gallin, D. (2001). Propositions on trade unions and informal employment in times of globalisation. Antipode, 33(3), 531-49. http://dx.doi.org/10.1111/1467-8330.00197

Geertz, C. (1963). Old Societies and New States: The quest for modernity in Asia and Africa. Free Press of Glencoe, New York.

Gibson-Graham, J-K. (2006). The End of Capitalism (As We Knew It): A Feminist Critique of Political Economy. University of Minnesota Press, Minneapolis.

Gilbert, A. (1998). The Latin American City. Monthly Review Press, New York.

Gurtoo, A., \& Williams, C.C. (2009). Entrepreneurship and the informal sector: some lessons from India. International Journal of Entrepreneurship and Innovation, 10(1), 55-62. http://dx.doi.org/10.5367/000000009787414280

Hall, P., \& Soskice, D. (Eds.). (2001). Varieties of Capitalism: The Institutional Foundations of Comparative Advantage. Oxford University Press, Oxford. http://dx.doi.org/10.1093/0199247757.001.0001

Hudson, R. (2005). Economic Geographies: circuits, flows and spaces. Sage, London.

Hussmanns, R. (2005). Measuring the Informal Economy: from employment in the informal sector to informal employment. ILO Policy Integration Department/Bureau of Statistics, Working Paper No. 53, ILO, Geneva.

ILO. (2002). Women and Men in the Informal Economy: a statistical picture. International Labour Office, Geneva.

ILO. (2011). Statistical Update on Employment in the Informal Economy. ILO Department of Statistics, Geneva.

ILO. (2012). Statistical Update on Employment in the Informal Economy. ILO Department of Statistics, Geneva.

ILO. (2013). Women and Men in the Informal Economy: statistical picture. Retrieved 18 February 2014, from http://laborsta.ilo.org/informal_economy_E.html

Jütting, J.P., \& Laiglesia, J.R. (2009). Employment, poverty reduction and development: what's new? In Johannes, P., Jütting, J.P. and Laiglesi, J.R. (Eds.), Is Informal Normal? Towards more and better jobs in developing countries. OECD, Paris.

Lewis, A. (1955). The Theory of Economic Growth. Richard D. Erwin, Homewood, IL.

London, T., \& Hart, S.L. (2004). Reinventing strategies for emerging markets: beyond the transnational model. Journal of International Business Studies, 35, 350-70. http://dx.doi.org/10.1057/palgrave.jibs.8400099

Massey, D. (2005). For Space. Sage, London.

Nwabuzor, A. (2005). Corruption and development: new initiatives in economic openness and strengthened rule of law. Journal of Business Ethics, 59(1-2), 121-38. http://dx.doi.org/10.1007/s10551-005-3402-3

OECD. (2012). Reducing opportunities for tax non-compliance in the underground economy. OECD, Paris.

Oviedo, A.M., Thomas, M.R., \& Karakurum-Özdemir, K. (2009). Economic Informality: Causes, costs and policies - A literature survey. World Bank Working Paper No. 167, World Bank, Washington DC.

Packard, T. G. (2007). Do Workers in Chile Choose Informal Employment? A dynamic analysis of sector choice. World Bank Policy Research Paper No. 4232, World Bank, Washington DC.

Perry, G.E., \& Maloney, W.F. (2007). Overview. Informality: Exit and Exclusion. In G.E. Perry et al. (Eds.), Informality: Exit and Exclusion (pp. 1-19). IBRD/World Bank: Washington DC.

Pfau-Effinger, B. (2009). Varieties of undeclared work in European societies. British Journal of Industrial Relations, 47(1), 79-99. http://dx.doi.org/10.1111/j.1467-8543.2008.00711.x

Portes, A. (1994). The informal economy and its paradoxes. In Smelser, N.J. and Swedberg, R. (Eds.), The Handbook of Economic Sociology (pp. 142-65). Princeton University Press: Princeton.

Rani, U., Belser, P., Oelz, M., \& Ranjbar, S. (2013). Minimum wage coverage and compliance in developing countries. International Labour Review, 152(3-4), 381-410. 
Renooy, P., Ivarsson, S., van der Wusten-Gritsai, O., \& Meijer, R. (2004). Undeclared Work in an Enlarged Union: an analysis of shadow work - an in-depth study of specific items. European Commission, Brussels.

Rodgers, P., \& Williams, C.C. (2009). The informal economy in the former Soviet Union and in central and eastern Europe. International Journal of Sociology, 39(1), 3-11. http://dx.doi.org/10.2753/IJS0020-7659390200

Rohlf, W.D. (1998). Introduction to Economic Reasoning. Addison-Wesley, London.

Sassen, S. (1996). Service employment regimes and the new inequality. In Mingione, E. (Ed.), Urban Poverty and the Underclass (pp. 142-59). Basil Blackwell, Oxford. http://dx.doi.org/10.1002/9780470712900.ch3

Sauvy, A. (1984). Le Travail Noir et l'Economie de Demain. Calmann-Levy, Paris.

Schneider, F. (Ed.). (2008). The Hidden Economy. Edward Elgar, Cheltenham.

Schneider, F. (Ed.). (2011). Handbook on the Shadow Economy. Edward Elgar, Cheltenham.

Schneider, F. (2013). Size and Development of the Shadow Economy of 31 European and five other OECD countries from 2003 to 2013: A further decline. Johannes Kepler University, Linz. Retrieved 14 February 2014, from www.econ.jku.at/members/Schneider/files/publications/2013/ShadEcEurope31_Jan2013.pdf

Schneider, F., \& Williams, C.C. (2013). The Shadow Economy. Institute of Economic Affairs, London. http://dx.doi.org/10.1017/CBO9781139542289

Slavnic', Z. (2010). Political economy of informalization. European Societies, 12(1), 3-23.

Small Business Council. (2004). Small Business in the Informal Economy: making the transition to the formal economy. Small Business Council, London.

Taiwo, O. (2013). Employment choice and mobility in multi-sector labour markets: Theoretical model and evidence from Ghana. International Labour Review, 152(3-4), 469-92. http://dx.doi.org/10.1111/j.1564-913X.2013.00189.x

Transparency International. (2013). Corruption Perceptions Index (CPI). Retrieved 12 September 2013, from http://www.transparency.org/research/cpi/cpi_2007

Vanderseypen, G., Tchipeva, T., Peschner, J., Rennoy, P., \& Williams, C.C. (2013). Undeclared work: recent developments. In European Commission (Ed.), Employment and Social Developments in Europe 2013 (pp. 231-74). European Commission, Brussels.

Williams, C.C. (2007). Rethinking the Future of Work: directions and visions. Palgrave Macmillan, Basingstoke.

Williams, C.C. (2013). Evaluating cross-national variations in the extent and nature of informal employment in the European Union. Industrial Relations Journal, 44(5-6), 479-94. http://dx.doi.org/10.1111/irj.12030

Williams, C.C., \& Lansky, M. (2013). Informal employment in developed and developing economies: perspectives and policy responses. International Labour Review, 152(3-4), 355-80. http://dx.doi.org/10.1111/j.1564-913X.2013.00196.x

Williams, C.C., \& Nadin, S. (2012). Tackling the hidden enterprise culture: government policies to support the formalization of informal entrepreneurship. Entrepreneurship and Regional Development, 24(9-10), 895-915. http://dx.doi.org/10.1080/08985626.2012.742325

Williams, C.C., \& Round, J. (2009). Evaluating informal entrepreneurs' motives: some lessons from Moscow. International Journal of Entrepreneurial Behaviour and Research, 15(1), 94-107. http://dx.doi.org/10.1108/13552550910934477

Williams, C.C., Nadin, S., \& Rodgers, P. (2012). Evaluating competing theories of informal entrepreneurship: some lessons from Ukraine. International Journal of Entrepreneurial Behaviour and Research, 18(5), 528-43. http://dx.doi.org/10.1108/13552551211253919

Williams, C.C., Round, J., \& Rodgers, P. (2013). The Role of Informal Economies in the Post-Soviet World: the end of transition? Routledge, London.

World Bank. (2013). World Development Indicators. World Bank, Washington DC. Retrieved 18 December 2013, from http://data.worldbank.org/data-catalog/world-development-indicators

Yamada, G. (1996). Urban informal employment and self-employment in developing countries: theory and evidence. Economic Development and Cultural Change, 44(2), 244-66. http://dx.doi.org/10.1086/452214 